\author{
ANNA JUPOWICZ-GINALSKA \\ ORCID: 0000-0002-7016-0427 \\ Uniwersytet Warszawski \\ JUSTYNA JASIEWICZ \\ ORCID: 0000-0002-8869-0792 \\ Uniwersytet Warszawski \\ MAŁGORZATA KISILOWSKA \\ ORCID: 0000-0001-5733-5424 \\ Uniwersytet Warszawski \\ TOMASZ BARAN \\ ORCID: 0000-0003-2922-7551 \\ Uniwersytet Warszawski, \\ ALEKSANDER WYSOCKI \\ Panel Badawczy Ariadna
}

\title{
Fear of missing out a korzystanie z urządzeń umożliwiających dostęp do mediów społecznościowych na podstawie badań polskich internautów
}

DOI: 10.19195/2083-7763.9.17

\section{Wstęp}

Autorzy raportu 2018 Q4 Global Digital Statshot podają, że z mediów społecznościowych we wrześniu 2018 roku skorzystało około 3,4 mld ludzi na świecie (o 10\% więcej niż przed rokiem) ${ }^{1}$. Popularnym narzędziem umożliwiającym łączenie się z tego typu platformami jest naturalnie smartfon. Potwierdzają to na przykład badania konsumenckie przeprowadzone przez Honor i Kantar Millward Brown w 2018

1 Ł. Majchrzyk, Raport „Mobile i digital w 4Q 2018” - prawie 4,2 mld ludzi online!, 2018, https://mobirank.pl/2018/10/18/raport-mobile-i-digital-w-4q-2018-prawie-42-mld-ludzi-online/ (dostęp: 1.12.2018). 
roku, według których 78\% Europejczyków „wchodzi” w social media właśnie dzięki niemu (głównie kobiety i przedstawiciele grupy wiekowej 15-24) 2 .

Według opracowania Digital in 2018 w Polsce niemal połowa internautów korzysta „aktywnie z social mediów, a 37\% sięga po smartfony w celu komunikacji społecznościowej" ${ }^{3}$. W innym dokumencie można przeczytać, że Polacy na platformach społecznościowych przebywają codziennie przez 1 godzinę i 45 minut $^{4}$. Z kolei w badaniach przeprowadzonych na zlecenie Izby Gospodarki Elektronicznej (IGE) w 2016 roku aż 84\% respondentów zadeklarowało, że ma konto w serwisie społecznościowym, 63\% zaś, że korzysta z niego regularnie (najczęściej były to osoby w wieku od 15 do 24 lat, ale wysoki wskaźnik, bo oscylujący między $59 \%$ a $67 \%$, utrzymywał się także wśród grup do 44 . roku życia) ${ }^{5}$. Z kolei według raportu Newspoint po social media sięga już ponad $90 \%$ polskich internautów ${ }^{6}$.

Dotychczasowe analizy dowodzą, że w celu użytkowania omawianych platform Polacy najczęściej posługują się laptopem (68\%), smartfonem (66\%), komputerem stacjonarnym (57\%) i tabletem $(37 \%)^{7}$. Z kolei badania rynku telefonów komórkowych z 2017 roku wskazują, że konta w serwisach społecznościowych obsłużyło przez ten nośnik blisko 30\% konsumentów (więcej o 7\% w stosunku do ubiegłego roku) ${ }^{8}$. Jak jednak zauważają autorzy komunikatu (Nad)używanie smartfonów, „w ostatnich latach wzrost odsetka tych, którzy korzystają z telefonów z ekranem dotykowym, jest bardzo dynamiczny i sprawia, że ten typ telefonu komórkowego staje się coraz powszechniejszy — od sierpnia 2017 roku do października 2018 odsetek osób deklarujących, że używają smartfona, zwiększył się z 57\% do 68\%" 9 . Nie będzie więc przesadą stwierdzenie, że wraz z rosnącą popularnością tego narzędzia - szczególnie wśród najmłodszych — jego funkcje również będą się wzmacniać, w tym ta związana z łączeniem się z social media.

2 A. Stando, Smartfony maja dla nas różne funkcje. Do tego używamy ich najczęściej, 2018, https://tech.wp.pl/smartfony-maja-dla-nas-rozne-funkcje-do-tego-uzywamy-ich-najczesciej-6299495768856705a (dostęp: 1.12.2018).

3 Ł. Majchrzyk, Mobile i digital w 2018 roku w Polsce i na świecie, https://mobirank.pl/2018/02/02/ mobile-i-digital-w-2018-roku-w-polsce-i-na-swiecie/ (dostęp: 1.12.2018).

${ }^{4}$ M. Kuchta, Ilu użytkowników na świecie korzysta z mediów społecznościowych?, 2017, https://socialpress.pl/2017/02/ilu-uzytkownikow-na-swiecie-korzysta-z-mediow-spolecznosciowych (dostęp: 1.12.2018).

${ }^{5}$ Izba Gospodarki Elektronicznej, Lubię to czy kupuję to, 2016, s. 8 http://www.ecommercepolska.pl/files/3814/7074/8959/LubieToCzyKupujeTo_SocialCommerce_Sierpien2016.pdf (dostęp: 1.12.2018).

${ }^{6}$ R. Sadowski, Raport Newspoint: Pokolenia w Polsce i potrzeba monitorowania ich rosnacej aktywności, 2018, https://blog.newspoint.pl/index.php/2018/03/21/raport-newspoint-pokolenia-w-polsce-i-potrzeba-monitorowania-ich-rosnacej-aktywnosci/ (dostęp: 1.12.2018).

7 Izba Gospodarki Elektronicznej, op. cit.

8 Ł. Majchrzyk, Jak korzystamy ze smartfonów w 2018 roku? 2018, https://mobirank.pl/2018/07/02/ jak-korzystamy-ze-smartfonow-w-2018-roku-infografika/ (dostęp: 1.12.2018).

9 CBOS, (Nad)używanie smartfonów, Komunikat z badań 2018, nr 157, s. 1. 
Biorąc pod uwagę przedstawione dane, można przyjąć, że zarówno portale społecznościowe, jak i ich nośniki na stałe wpisały się we współczesny pejzaż medialny, wraz ze swoimi licznymi zaletami i wadami. Wśród tych pierwszych znajdują się chociażby: angażowanie uczestników, budowanie dynamicznego dialogu, dzielenie się doświadczeniami, powszechny i wolny dostęp, kreowanie i szerzenie informacji przez użytkowników, natychmiastowość, modyfikowalność, globalność czy pomoc w nawiązywaniu relacji międzyludzkich ${ }^{10}$.

Potencjał platform społecznościowych dostrzeżono między innymi w zakresie komunikacji marketingowej ${ }^{11}$, edukacji ${ }^{12}, \mathrm{CSR}^{13}, \mathrm{HR}^{14}$, kultury ${ }^{15}$, religii ${ }^{16}$ czy polityki ${ }^{17}$. Oczywiście lista nie jest wyczerpująca - pokazuje tylko, jak interdyscyplinarne i wszechobecne są dziś social media.

Podnoszone są również kwestie związane między innymi z „cyfrowym darwinizmem" ${ }^{18}$, niemałym udziałem social media w kreowaniu i rozprzestrzenianiu

10 Por. K. Fabjanik-Czerniak, Internetowe media społecznościowe jako narzędzie public relations, [w:] Zarzadzanie w sytuacjach kryzysowych niepewności, red. K. Kubiak, Warszawa 2012, s. 184-185; M. Dorenda-Zaborowicz, Marketing w social media, „Nowe Media” 2012, nr 3, s. 60.

11 Por. A. Bajdak, Nowe media w komunikacji marketingowej przedsiębiorstw, „Handel Wewnętrzny" 2017, nr 2, s. 17-27; I. Kuchciak, Social media jako element strategii banków opartej na budowaniu relacji z konsumentami, „Zarządzanie i Finanse” 10, 2012, nr 4, cz. 1, s. 349-366; M. Syrkiewicz-Świtała, Facebook - medium komunikacji marketingowej w ochronie zdrowia, „Zarządzanie Mediami" 2015, nr 3, s. 197-205.

12 Por. C. Greenhow, C. Lewin, Social media and education: Reconceptualizing the boundaries of formal and informal learning, „Learning, Media and Technology” 41, 2016, nr 1, s. 1-25; J. Paliszkiewicz, Rola mediów społecznościowych w innowacyjnym kształceniu, [w:] Innowacje w zarządzaniu i inżynierii, t. 2, red. R. Knosala, Opole 2016, s. 914-920.

13 W. Leoński, Wykorzystywanie mediów społecznościowych w CSR, „Studia Ekonomiczne. Zeszyty Naukowe Uniwersytetu Ekonomicznego w Katowicach” 2016, nr 300, s. 109-119.

14 Por. K. Mierzejewska, Technologie informacyjno-komunikacyjne $w$ zarządzaniu zasobami ludzkimi, „Acta Universitatis Nicolai Copernici. Zarządzanie” 2017, nr 1, s. 73-83.

15 Por. K. Walotek-Ściańska, Ocena poziomu wykorzystania mediów społecznościowych przez teatry publiczne $w$ województwie śląskim $w$ świetle badań empirycznych, „Studia Ekonomiczne. Zeszyty Naukowe Uniwersytetu Ekonomicznego w Katowicach" 2017, nr 321, s. 183-196.

16 Por. P. Radzyński, Social media w Kościele. Jak je wykorzystywać?, 2015, https://www.deon.pl/ religia/wiara-i-spoleczenstwo/art,1138,social-media-w-kosciele-jak-je-wykorzystywac.html (dostęp: 1.12.2018).

17 Por. M. Winiarska-Brodowska, Political communication in the EU: Civic potential of new media (case study: Poland), „Central European Journal of Communication” 2018, nr 8, s. 235-246.

18 M. Dorenda-Zaborowicz, op. cit. 
kryzysów wizerunkowych ${ }^{19}$ i fake newsó $w^{20}$, bezpieczeństwem danych ${ }^{21}$, negatywnym wpływem na dobre samopoczucie psychiczne, a w skrajnych przypadkach także na zdrowie użytkowników. Coraz częściej pojawiają się raporty i opracowania naukowe, które wiążą platformy bezpośrednio między innymi z uzależnieniem ${ }^{22}$, depresją $^{23}$, niską samooceną ${ }^{24}$, rozproszeniem uwagi ${ }^{25}$, narcyzmem ${ }^{26}$ czy fear of missing out.

\section{Fear of missing out (FOMO) — wprowadzenie teoretyczne}

Początkowo zjawiska fear of missing out nie wiązano z mediami społecznościowymi. Dan Herman w latach 90. XX w. zdefiniował je jako obawę przed niewykorzystaniem wszystkich dostępnych możliwości i jednoczesną utratą spodziewanej

19 Por. A. Jaworska, Jak marki (nie) radza sobie z kryzysem w social media. Przykłady zarządzania w kryzysie, „Nowe Media” 2014, nr 4, s. 59-87; M. Nowak, Nie tylko Tiger, czyli 5 największych w Polsce wpadek w mediach społecznościowych, 2018, https://www.spidersweb.pl/2018/03/najwieksze-wpadki-kryzysy-media-spolecznosciowe.html (dostęp: 1.12.2018).

20 Por. H. Allcott, M. Gentzkow, Social media and fake news in the 2016 election, „Journal of Economic Perspectives" 2017, nr 2, s. 211-236; D. Spohr, Fake news and ideological polarization: filter bubbles and selective exposure on social media, „Business Information Review” 2017, $\mathrm{nr}$ 3, s. $150-160$.

21 J. Sosnowska, Wyciek danych z Facebooka. 50 milionów kont zagrożonych, 2018, http://wyborcza.pl/7,156282,23981124,wyciek-danych-z-facebooka-50-milionow-kont-zagrozonych.html (dostęp: 1.12.2018).

22 P. Wallace, Internet addiction disorder and youth, „EMBO Reports” 15, 2014, nr 1, s. 12-16, https://www.ncbi.nlm.nih.gov/pmc/articles/PMC4303443/ (dostęp: 1.12.2018); L. Monacis et al., Social networking addiction, attachment style, and validation of the Italian version of the Bergen Social Media Addiction Scale, „Journal of Behavioral Addictions” 2017, nr 2, s. 178-186.

23 Por. A. Shensa et al., Problematic social media use and depressive symptoms among U.S. young adults: A nationally-representative study, „Social Science \& Medicine” 2017, nr 182, s. 150-157; C.R. Blease, Too many 'friends,' too few 'likes'? Evolutionary psychology and 'Facebook depression', „Review of General Psychology” 19, 2015, nr 1, s. 1-13.

${ }^{24}$ H.C. Woods, H. Scott, \#Sleepyteens: Social media use in adolescence is associated with poor sleep quality, anxiety, depression and low self-esteem, „Journal of Adolescence” 51, 2016, s. 41-49.

${ }_{25}$ T. Kiisel, Is social media shortening our attention span?, 2012, https://www.forbes.com/sites/ tykiisel/2012/01/25/is-social-media-shortening-our-attention-span/ (dostęp: 1.12.2018).

${ }^{26}$ C.S. Andreassen, S. Pallessen, M.D. Griffiths, The relationship between addictive use of social media, narcissism, and self-esteem: Findings from a large national survey, „Addictive Behaviors” 2017, nr 64, s. 287-293; T.C. Marshall, K. Lefringhausen, N. Ferenczi, The Big Five, self-esteem, and narcissism as predictors of the topics people write about in Facebook status updates, „Personality and Individual Differences" 2015, nr 85, s. 35-40. 
radości związanej z wyczerpaniem wszystkich tych możliwości ${ }^{27}$, dekadę później zaś Patrick McGinnis określił je jako „nadoptymalizowanie”28.

Termin zyskał ogromną popularność między innymi dzięki środkom przekazu, które powiązały go z social mediami. Wzajemne relacje między FOMO a platformami społecznościowymi potwierdził w 2013 roku zespół badaczy, którzy opublikowali jeden z najważniejszych artykułów naukowych poświęconych omawianemu fenomenowi ${ }^{29}$. W Motivational, emotional, and behavioral correlates of fear of missing out autorzy nie tylko zdefiniowali zjawisko, lecz także opracowali tak zwaną skalę FOMO. Był to zestaw dziesięciu stwierdzeń rozpiętych na skali Likerta, dzięki którym możliwe stało się oszacowanie poziomu „sfomowania”.

Andrew K. Przybylski, Kou Murayama, Cody R. DeHaan i Valerie Gladwell wykazali także, że osoby o wyższym FOMO to raczej ludzie młodzi, a także częściej korzystający z mediów społecznościowych, na przykład w trakcie prowadzenia samochodu czy też podczas wykładów. Rozumienie akronimu zaproponowane przez uczonych — „wszechogarniający lęk, że inne osoby w danym momencie przeżywają bardzo satysfakcjonujące doświadczenia, w których ja nie uczestniczę" ${ }^{30}$ — zostało zaakceptowane przez środowisko akademickie na świecie.

Obecnie kolejne, coraz liczniejsze teksty na temat fear of missing out nawiązują do zacytowanej definicji ${ }^{31}$, uwypuklając jednak znaczącą rolę social mediów. W tym kontekście są one widziane przez pryzmat niekontrolowanego korzystania

27 D. Herman, The Fear of Missing Out (FOMO), 2010, http://www.danherman.com/TheFear-of-Missing-Out-(FOMO)-by-Dan-Herman.html (dostęp: 1.12.2018).

${ }^{28} \mathrm{~K}$. Knowles, Meet the man behind FOMO, „The MEMO”, 22.03.2016, https://www. thememo.com/2016/03/22/fomo-patrick-mcginnisbook-the-10-entrepreneur-fomo-meme/ (dostęp: 1.12.2018).

29 A.K. Przybylski et al., Motivational, emotional, and behavioral correlates of fear of missing out, „Computers in Human Behavior” 4, 2013, s. 1841-1848.

30 Ibidem, s. 1841.

31 Por. L. Dossey, FOMO, digital dementia, and our dangerous experiment, „Explore: The Journal of Science and Healing” 10, 2014, nr 2, s. 69-73; I. Beyens, E. Frison, S. Eggermont, „I don't want to miss a thing": Adolescents' fear of missing out and its relationship to adolescents' social needs, Facebook use, and Facebook related stress, "Computers in Human Behavior” 64, 2016, s. 1-8; D. Collins, Loss aversion bias or fear of missing out: A behavioural economics analysis of compensation in investor-state dispute settlement, „Journal of International Dispute Settlement” 8, 2016, nr 3, s. 460-482; B.A. Larkin, J.S. Fink, Fantasy sport, FoMO, and traditional fandom: How second-screen use of social media allows fans to accommodate multiple identities, „Journal of Sport Management” 30, 2016, nr 6, s. 643-655; S.L. Buglass et al., Motivators of online vulnerability: The impact of social network site use and FOMO, „Computers in Human Behavior” 66, 2017, s. 248-255; U. Oberst et al., Negative consequences from heavy social networking in adolescents: The mediating role of fear of missing out, „Journal of Adolescence" 55, 2017, s. 51-60; C.A. Wolniewicz et al., Problematic smartphone use and relations with negative affect, fear of missing out, and fear of negative and positive evaluation, „Psychiatry Research" 2018, nr 262, s. 618-623. 
z nich, w tym ciągłego sprawdzania i odświeżania profili, uzależnienia od aplikacji (a także informacji) czy nawet chęci uniknięcia złego samopoczucia ${ }^{32}$.

Za FOMO stoją chociażby silna potrzeba przynależności do grupy, z którą pragnęłoby się identyfikować, lęk przed „odłączeniem” od źródła informacji (inaczej poczucie „wypadnięcia z obiegu”), obawa przed utratą satysfakcjonujących doświadczeń lub relacji, a nawet tendencja do popadania $\mathrm{w}$ depresję ${ }^{33}$. Wszystkie wymienione cechy można uznać zarówno za przyczynę, jak i skutek zjawiska: wydaje się, że syndrom ten jest niczym spirala, z której bardzo ciężko się wyzwolić. Rządzi nią prosty mechanizm: im bardziej dana osoba czuje się „odłączona”, tym bardziej chce uzupełnić wszystkie braki, kompulsywnie korzystając z wszystkiego, co pomoże jej to zrobić. Okazuje się jednak, że informacji, ich źródeł i nośników jest nieskończenie wiele, $\mathrm{w}$ związku z czym nie da się zapoznać z nimi wszystkimi. Wybierając którąś z nich, nie wybierze się więc innych, pozostając tym samym $\mathrm{w}$ poczuciu permanentnego niedoinformowania i zarazem przeciążenia informacjami (z powodu próby zapoznania się z jak największą ich liczbą).

\section{Projekt fear of missing out w Polsce — założenia badawcze, metodologia, analiza danych i skala występowania zjawiska}

\subsection{Założenia badawcze projektu}

Paradoks FOMO, w dużej mierze polegający na współwystępowaniu wykluczających się wartości, dowodzi złożoności i interdyscyplinarności tego zjawiska.

32 T.L. James et al., The effect of belongingness on obsessive-compulsive disorder in the use of online social networks, „Journal of Management Information Systems” 34, 2017, nr 2, s. 560-596; P.R. Hetz, C.L. Dawson, T.A. Cullen, Social media use and the fear of missing out (FoMO) while studying abroad, "Journal of Research on Technology in Education” 47, 2015, nr 4, s. 259-272; L. Auverset, A. Billings, L. Conlin, Time-shifting vs. appointment viewing: the role of fear of missing out within TV consumption behaviors, „Communication \& Society” 29, 2016, nr 4, s. 151-164; J.D. Elhai et al., Fear of missing out, need for touch, anxiety and depression are related to problematic smartphone use, „Computers in Human Behavior” 63, 2016, s. 509-516; Ł. Tomczyk, E. SelmanagicLizde, Fear of Missing Out (FOMO) among youth in Bosnia and Herzegovina - Scale and selected mechanisms, "Children and Youth Services Review” 88, 2018, s. 541-549; J. Fox, J.J. Moreland, The dark side of social networking sites: An exploration of the relational and psychological stressors associated with Facebook use and affordances, „Computers in Human Behavior 45, 2015, s. 168-176.

33 D. Alt, Students' social media engagement and fear of missing out (FoMO) in a diverse classroom, „Journal of Computing in Higher Education” 2017, nr 2, s. 388-410; eadem, Students' wellbeing, fear of missing out, and social media engagement for leisure in higher education learning environments, „Current Psychology” 2018, nr 1, s. 128-138; C.T. Barry et al., Adolescent social media use and mental health from adolescent and parent perspectives, "Journal of Adolescence" 61, 2017, s. 1-11; A. Błachnio, A. Przepiórka, Facebook intrusion, fear of missing out, narcissism, and life satisfaction: A cross-sectional study, „Psychiatry Research” 259, 2018, s. 514-519; Z.G. Baker, H. Krieger, A.S. LeRoy, Fear of Missing Out: Relationships with depression, mindfulness, and physical symptoms, „Translational Issues in Psychological Science” 2, 2016, nr 3, s. 275-282. 
$\mathrm{Na}$ ten fenomen składają się zarówno wątki medyczne, psychologiczne, socjologiczne, marketingowe, jak i komunikacyjne, a samo fear of missing out może w różnym natężeniu pojawiać się w kontekście praktycznie każdej dziedziny życia ludzkiego, począwszy od zdrowia psychicznego i fizycznego, przez politykę, zakupy i rozrywkę, a na wierze skończywszy.

Mimo niewątpliwie rosnącego zainteresowania zjawiskiem ${ }^{34}$ jak dotąd FOMO bada się głównie za pomocą metod niereprezentatywnych lub ewentualnie jakościowych. Dotychczas w Polsce nie pojawiło się ani jedno badanie, które - opierając się na danych reprezentatywnych - liczbowo przedstawiałoby skalę występowania zjawiska w kraju. Po raz pierwszy dokonali tego autorzy niniejszego tekstu, którzy opracowali raport pt. FOMO. Polacy a lęk przed odłączeniem, opublikowany 16 października 2018 roku $^{35}$. Był on efektem prac nad projektem, któremu przyświecał cel precyzyjnego wskazania zakresu występowania fear of missing out wśród polskich internautów (między innymi przez wyliczenie wskaźnika FOMO i przedstawienie jego cech charakterystycznych w kontekście użytkowania mediów społecznościowych).

Przedsięwzięcie to miało czteroetapowy charakter i składało się z:

1. Analizy literatury przedmiotu, dokonanej na podstawie tekstów naukowych dostępnych w Web of Science, a odnalezionych za pomocą instrukcji wyszukiwawczej „FOMO” OR „Fear of Missing Out” OR („FOMO” AND „Fear of Missing Out") - bez przyjęcia początkowej cezury czasowej, a aktualizowanej do końca grudnia 2018 roku, z uwzględnieniem wszystkich baz tematycznych.

2. Reprezentatywnych badań ilościowych, opierających się na kwestionariuszu ankiety internetowej (dalsze informacje, ze względu na ich obszerność, zaprezentowano poniżej).

3. Popularyzacji wiedzy na temat zjawiska dzięki:

a) opracowaniu raportu badawczego pt. FOMO. Polacy a lęk przed odłaczeniem $^{36}$, (znalazły się w nim między innymi najważniejsze dane ankietowe oraz rekomendacje na temat cyfrowego dobrostanu);

b) współpracy z mediami w celu nagłośnienia istoty zjawiska, jego przyczyn, skutków i sposobu przeciwdziałania mu (zgromadzono ponad 140 publikacji, w tym w najpopularniejszych polskich środkach przekazu ${ }^{37}$ ).

4. Pracy naukowej nad opracowaniem pozyskanych danych.

34 W kontekście naukowym wystarczy spojrzeć na przyrost liczby tekstów naukowych poświęconych FOMO, na przykład w Web of Science (po wpisaniu w wyszukiwarkę instrukcji wyszukiwawczej „FOMO” lub „Fear of Missing Out”); w kontekście zaś reakcji użytkowników sieci na wykres Google Trends (po wpisaniu tych samych wyrażeń). Okazuje się, że w obu przypadkach rezultaty układają się w trend rosnący intensywnie od 2013 roku.

35 A. Jupowicz-Ginalska et al., FOMO. Polacy a lęk przed odłączeniem, Warszawa 2018, http:// www.wdib.uw.edu.pl/fomo (dostęp: 1.12.2018).

36 Ibidem.

37 WDIB UW, Media o raporcie „FOMO. Polacy a lęk przed odłaczeniem”, 2018, https://www. wdib.uw.edu.pl/media-o-raporcie-fomo-polacy-a-lek-przed-odlaczeniem (dostęp: 1.12.2018). 


\subsection{Metodologia badań projektu FOMO w Polsce — dane podstawowe}

Głównym problemem badawczym projektu, jak wspomniano, było poznanie skali zjawiska FOMO wśród polskich internautów od 15 lat wzwyż na podstawie danych reprezentatywnych.

Poprzez rozbudowaną analizę literatury przedmiotu zamierzaliśmy osiągnąć następujące cele: przygotowanie fundamentu teoretycznego pod dalsze badania ilościowe oraz jakościowe; zapoznanie się z definicjami, cechami, uwarunkowaniami występowania FOMO na świecie; pogłębienie wiedzy na temat metod i narzędzi, używanych w celu badania FOMO; analiza występujących ograniczeń zarówno w badaniach fenomenu, jaki w prognozach co do dalszych badań. Należy zaznaczyć, że w ramach analizy literatury przedmiotu zrezygnowaliśmy z postawienia hipotez, ponieważ ta część badania miała charakter stricte ekstrapolacyjny. Wykorzystanym zaś przez nas narzędziem badawczym był arkusz badawczy, w którym kolejne teksty naukowe kodowaliśmy według przyjętego wcześniej klucza kategoryzacyjnego.

Z kolei poprzez realizację badań ilościowych (reprezentatywnych) zamierzaliśmy osiągnąć następujące cele: liczbowe wykazanie natężenia zjawiska wśród polskich internautów w zależności od zmiennych demograficznych (wieku, płci oraz miejsca zamieszkania respondentów); implementacja „skali FOMO” opracowanej przez A.K. Przybylskiego et al. w 2013 roku; wykazanie przyczyn i skutków odczuwania fear of missing out; zbadanie powiązań między FOMO a: użytkowaniem social mediów i nowych technologii, komunikacją marketingową w internecie, autoprezentacją, samooceną i samopoczuciem respondentów powiązanymi z intensywnością i jakością nawiązywanych przez nich relacji międzyludzkich.

W badaniu, ze względu na jego wielowątkowość i interdyscyplinarność, intencjonalnie przyjęliśmy hipotezy o charakterze generalnym: H1) internauci cierpiący na wysokie FOMO wykazują większe niż osoby z tak zwanej grupy ogólnej zainteresowanie cyfrowym aspektem współczesnego życia; H2) wiek to zmienna demograficzna najsilniej różnicująca FOMO w Polsce; H3) idea FOMO łączy się z szeroko rozumianym "dobrostanem cyfrowym”, samooceną, samopoczuciem, zdolnością nawiązywania i utrzymywania relacji międzyludzkich i najczęściej wpływa na nie negatywnie.

Narzędziem badawczym wykorzystywanym w badaniach ilościowych był kwestionariusz ankiety. Jego pierwszą wersję opracowaliśmy w styczniu 2018 roku. Właściwie badanie, po wykonaniu pretestu w lutym 2018 roku (na niereprezentatywnej grupie studentów Wydziału Dziennikarstwa, Informacji i Bibliologii UW) i naniesieniu odpowiednich korekt, przeprowadziliśmy na panelu Ariadna w dniach 18-28 marca 2018 roku na próbie ogólnopolskiej dla osób od 15 lat wzwyż $(\mathrm{N}=1060)$. Kwoty dobrano według reprezentacji w populacji polskich internautów dla płci, wieku i wielkości miejscowości zamieszkania. Skorzystano z metody CAWI (ang. Computer Assisted Web Interview). 
Kwestionariusz składał się z 499 pytań szczegółowych, z czego 475 ułożono $\mathrm{w}$ formie skali Likerta (trzy przyjęły postać dwubiegunowej skali porządkowej, pozostałe zaś - pięciopunktowej). Pytania w przeważającej większości miały charakter zamknięty (otwartych pozostało 9) oraz jednokrotnego wyboru (tylko 1 wielokrotnego wyboru).

Dane pozyskane dla każdego z 499 pytań ujęto w kontekście demograficznym (to znaczy płci, wieku, miejsca zamieszkania, stanu cywilnego, posiadanego potomstwa, formy zatrudnienia) oraz postaw i obowiązków obywatelskich (zrealizowane i deklarowane uczestnictwo w wyborach, preferencje polityczne ze wskazaniem na konkretną partię).

Wszystkie pytania uporządkowano tematycznie w następujące grupy (nie wliczając demografii oraz obowiązków obywatelskich):

1. Skala FOMO według Andrew K. Przybylskiego et al. i jej implementacja w Polsce.

2. Ogólne użytkowanie mediów społecznościowych, analizowane przez pryzmat rodziny, znajomych, polityków i partii politycznych, marek, gwiazd i celebrytów (zapytano między innymi o ulubione serwisy społecznościowe, częstotliwość i czas ich użytkowania, prowadzenie i obserwowanie profili, liczbę znajomych, preferencje co do formy zamieszczanych lub odbieranych treści, nośniki łączące z social media, zachowania na platformach społecznościowych itp.).

3. Cele użytkowania mediów społecznościowych z uwzględnieniem: pobudek prywatnych i zawodowych, a także roli social media na tle mediów tradycyjnych, jak również wyrażania i wysłuchiwania opinii oraz komunikowania się z innymi i utrzymywania kontaktu z nimi, zdobywania wiedzy, poszukiwania między innymi znajomości, pomysłów na spędzanie wolnego czasu, atrakcyjnych ofert cenowych, informacji, rozrywki, inspiracji (miejscami również w odniesieniu do rodziny, znajomych, polityków i partii politycznych, marek, gwiazd i celebrytów).

4. Pozytywne i negatywne skutki użytkowania mediów społecznościowych (między innymi samoograniczanie się w korzystaniu z social media, poczucie bycia „przeinformowanym”, nawyki korzystania uwarunkowane czasem, miejscem i okolicznościami, ukrywanie się z powodu zaglądania na platformy społecznościowe, oddziaływanie social media na kompetencje osobiste i zawodowe oraz na wyznaczanie i realizację celów, wpływ na więzi z bliższym i dalszym otoczeniem, jak również na samopoczucie i samoocenę, związki między brakiem dostępu do mediów społecznościowych lub urządzeń mobilnych a kondycją psychiczną i fizyczną badanych).

5. Wpływ mediów społecznościowych na budowanie własnego wizerunku za pomocą platform społecznościowych.

6. Aktywność marketingowa w mediach społecznościowych (między innymi zachowania zakupowe, skuteczność reklamy internetowej, podatność na rekomendacje).

7. Pytania ogólne dotyczące stanu psychicznego i fizycznego respondentów (na przykład oceny ich sytuacji materialnej, prywatnej i zawodowej, umiejętności określenia sensu życia), ich samooceny, postawy życiowej i światopoglądu. 


\subsection{Opracowanie wyników badań i skala występowania zjawiska w Polsce}

W jednym z bloków tematycznych kwestionariusza pojawiła się „skala FOMO” Andrew K. Przybylskiego et al. Posłużono się nią w celu ustalenia sposobu liczenia wskaźnika dla fear of missing out w Polsce, a następnie to rozwiązanie zastosowano w pozostałych 489 pytaniach. I tak, w ramach „skali FOMO” poproszono respondentów o wskazanie poziomu ich zgodności z poszczególnymi pytaniami na pięciopunktowej skali Likerta, gdzie wartość 0 oznaczała „W ogóle nieprawdziwe”, zaś 4 - „całkowicie prawdziwe”.

Odpowiedzi każdego respondenta podzielono przez 4 (czyli maksymalną wartość skali). Po zsumowaniu średnich wartości cząstkowych otrzymano średnie wyniki dla każdego z dziesięciu pytań w zakresie od 0 do 4 - wyższe dane wskazywały podwyższony poziom FOMO (należy podkreślić, że elementy składowe FOMO wykazały dobrą wewnętrzną spójność i rzetelność na poziomie $\alpha=0,89$ Cronbacha, potwierdzając poprzednie badania $\mathrm{w}$ tym temacie $\left.{ }^{38}\right)$.

Następnie opracowano indeks FOMO, który agregował pozyskane wyniki dla pytań ze „skali FOMO”. Przyjął on postać rekodowanego (przekształconego liniowo), całkowitego wyniku zestawu do zakresu wartości końcowej 0-100. Poziomy FOMO zidentyfikowano przez analizę SD (wykres 1). Wysokie odchylenie standardowe równe i większe ( $>1 \sigma$ ) wskazało wysoką wartość FOMO, na skali wyznaczając zakres 60-100. Niski indeks FOMO opierał się na wynikach równych i mniejszych niż $(-1 \sigma)$, uzyskując zakres $0-20$. Zakres wartości $21-59$ odnosił się zaś do osób o średnim stopniu „sfomowania”.

Na podstawie powyższych wyliczeń dokonano klasyfikacji fear of missing out na:

1. Niskie (low FOMO) - najniższy poziom deklaratywności wśród respondentów na twierdzenia ze „skali FOMO”. Oznacza to, że wśród internautów istnieje grupa, która wykazuje się najmniejszą obawą przed odłączeniem (wyniki poniżej 1SD, czyli jednego odchylenia standardowego).

2. Średnie (mid FOMO) - umiarkowany poziom deklaratywności wśród respondentów na twierdzenia ze „skali FOMO”. Oznacza to, że wśród internautów istnieje grupa, która wykazuje się przeciętną obawą przed odłączeniem (zakres między odchyleniem standardowym poniżej 1SD a powyżej 1SD).

3. Wysokie (high FOMO) - najwyższy poziom deklaratywności wśród respondentów na twierdzenia ze „skali FOMO”. Oznacza to, że wśród internautów istnieje grupa, która wykazuje się ponadprzeciętną obawą przed odłączeniem (wyniki powyżej 1SD, czyli jednego odchylenia standardowego).

38 Por. L. Reinecke et al., Digital stress over the life span: The effects of communication load and internet multitasking on perceived stress and psychological health impairments in a German probability sample, „Media Psychology” 2017, nr 1, s. 90-115; S.L. Buglass et al., op. cit. 


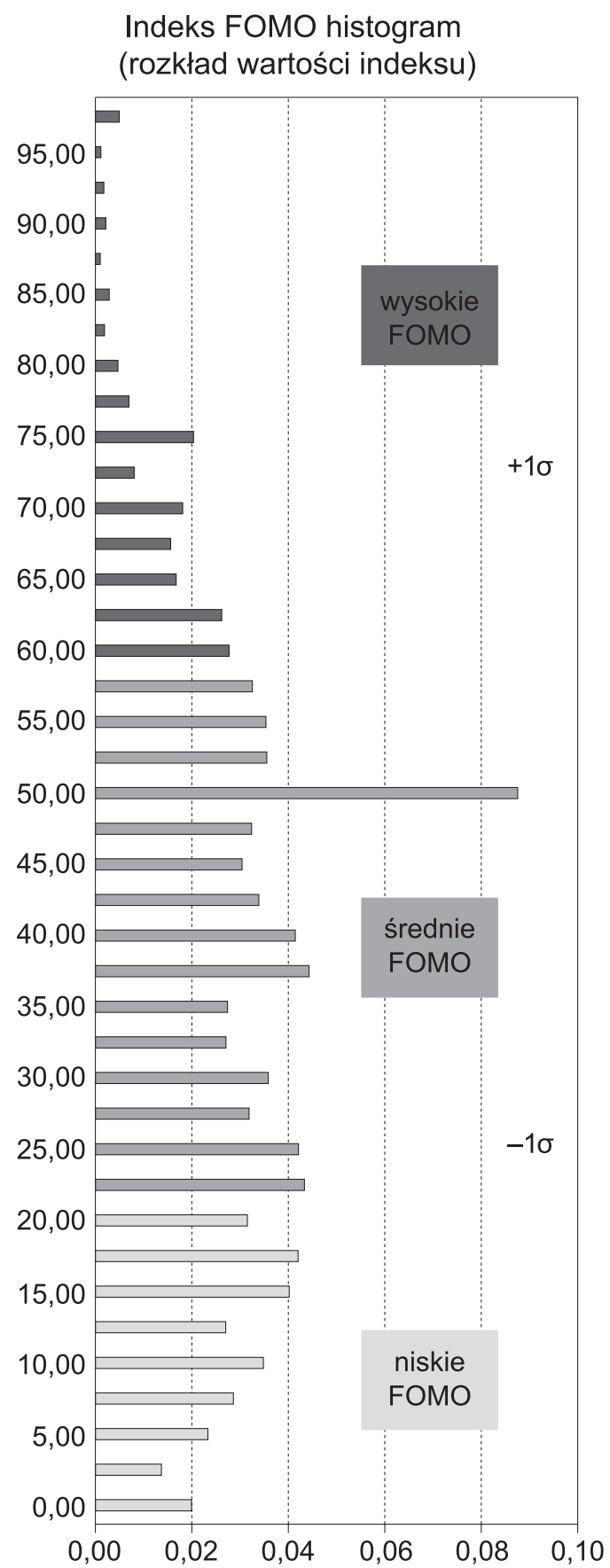

Wykres 1. „Skala FOMO” w Polsce — odchylenia standardowe Źródło: opracowanie własne. 
Po przekonwertowaniu wartości końcowej 0-100 na wartości procentowe uzyskano dane, które precyzyjnie określiły skalę fear of missing out w Polsce (wykres 2).

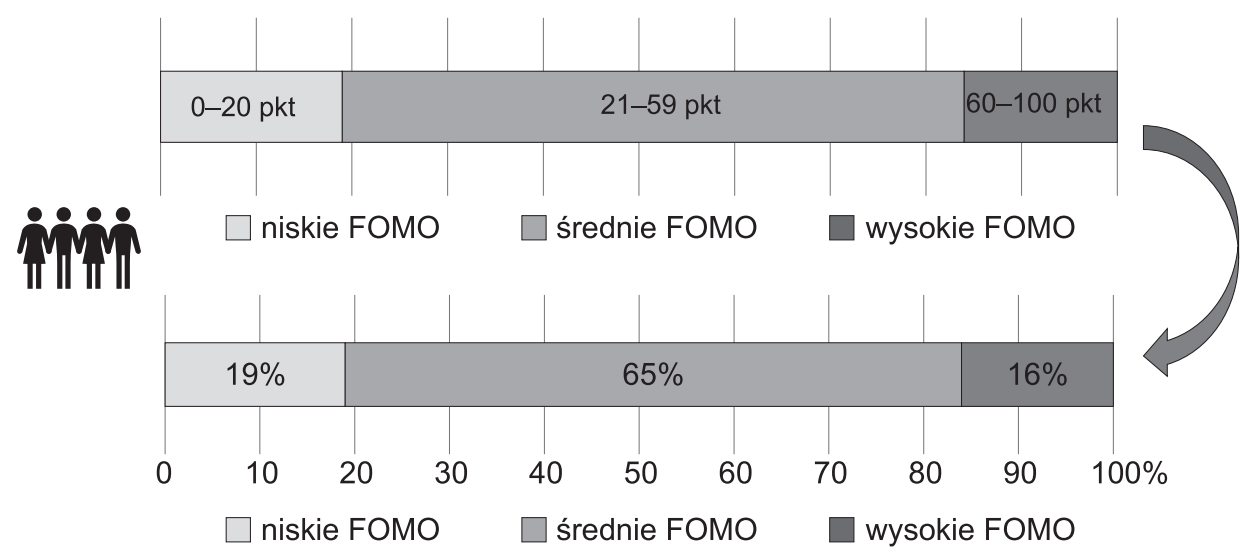

Wykres 2. Rekodowanie wartości 0-100 na wartości \%: niskie, średnie i wysokie FOMO

Źródło: opracowanie własne.

Aby dokładnie poznać skalę występowania zjawiska w kraju, wszystkie dane procentowe należy przełożyć na dane liczbowe.

W 2017 roku regularnie z internetu korzystało 72,7\% Polaków, czyli około $28 \mathrm{mln}$ (obecnie w kraju żyje około 38,434 mln Polaków). Spośród tych $28 \mathrm{mln} 91 \%$ (a więc około $25,5 \mathrm{mln}$ ) stanowili internauci powyżej 15. roku życia ${ }^{39}$. Oznacza to, że spośród owych 25,5 mln osób 19\% odczuwało FOMO niskie (około 4,9 mln), 65\% - średnie (około 16,6 mln), 16\% zaś - wysokie (około $4 \mathrm{mln}$ ).

Jak się okazuje, to wiek najbardziej różnicuje poziom fear of missing out. Na wysokie FOMO cierpi 21\% internautów z najmłodszej grupy badanych (15-24 lata), na średnie $-69 \%$, na niskie $-10 \%$. $\mathrm{Z}$ kolei w grupie 25-34 lata najsilniej FOMO odczuwa 17\% badanych (69\% — średnio, 14\% - nisko), wśród osób w przedziale 35-44 lata zaś jako wysoce „sfomowane” można określić 18\% (61\% — średnio, 21\% - nisko). W grupie wiekowej między 45. a 55. rokiem życia wysokie FOMO ma 12\% (60\% - średnie, a 28\% - niskie), powyżej 55. roku życia zaś najmocniejszy lęk odczuwa 5\% respondentów (65\% — średni, a 30\% - niski). Biorąc pod uwagę powyższe wyniki, można potwierdzić, że wraz z wiekiem maleje liczba osób odczuwających wysokie fear of missing out (zwiększa się jednocześnie odsetek internautów deklarujących niskie FOMO).

Druga zmienna demograficzna, czyli miejsce zamieszkania, umiarkowanie wpływa na analizowane zjawisko. Na wysokie FOMO cierpi 14\% rezydentów wsi, $16 \%$ - małych i średnich miast, a 18\% - dużych i wielkich miast. Średni stopień

39 GUS, Sytuacja demograficzna Polski do 2017 r. Urodzenia i dzietność, [b.m.], 2018, s. 11; IAB Polska, Raport strategiczny Internet 2017/2018, [b.m.], s. 8 . 
„sfomowania” najczęściej występuje u mieszkańców wsi (68\%), u pozostałych badanych zaś różni się on niewiele (jego odczuwanie potwierdza 65\% mieszkańców małych i średnich miast, a dużych i wielkich - 64\%). Najniższe FOMO dotyczy po $18 \%$ internautów mieszkających na wsi i w większych miejscowościach oraz 19\% tych, którzy rezydują w miastach średnich i małych. O ile zatem różnice między wsią a małymi/średnimi miastami albo małymi/średnimi miastami a dużymi/wielkimi miastami są nieznaczne, o tyle między wsią a największymi ośrodkami przyjmują już bardziej wyrazistą postać.

W odniesieniu do płci wskaźnik FOMO dla kobiet i mężczyzn jest porównywalny: wysoce „sfomowanych” jest $17 \%$ użytkowniczek internetu oraz $15 \%$ użytkowników, nisko zaś - 19\% kobiet i 18\% mężczyzn. Stan średniego lęku przed odłączeniem odczuwa 64\% internautek i 67\% internautów. Można zatem ostrożnie wnioskować, że w Polsce płeć respondentów nie wiąże się znacznie z natężeniem występowania FOMO (szczególnie w kontekście deklaracji o spolaryzowanym charakterze).

Jak widać, już w początkowej fazie analizy wyników pozytywnie zweryfikowana została hipoteza (H2): dowiedziono, że to wiek spośród innych zmiennych demograficznych najsilniej różnicuje FOMO w Polsce. Należy zaznaczyć, że pozostałe hipotezy także zostały potwierdzone, niemniej dane na ten temat — ze względu na ich obszerność i w trosce o jakość analizy - będą sukcesywnie prezentowane w kolejnych pracach naukowych.

\section{FOMO w Polsce a korzystanie z urządzeń umożliwiających dostęp do mediów społecznościowych — założenia badawcze dla części projektu będącej przedmiotem niniejszego opracowania}

W tej części tekstu skupiamy się wyłącznie na jednym z wątków naszego projektu badawczego, opierając się na danych dotyczących tego, w jaki sposób internauci łączą się z social mediami za pomocą konkretnych nośników.

Jak widać, przyjęty zakres badawczy odnosi się do dwóch ogólnych hipotez calego projektu, to jest: HI) internauci cierpiący na wysokie FOMO wykazują większe niż osoby z tak zwanej grupy ogólnej zainteresowanie cyfrowym aspektem współczesnego życia; HII) wiek to zmienna demograficzna najsilniej różnicująca FOMO w Polsce.

Mając w pamięci generalne założenia projektu, w trosce o jakość analizy postanowiliśmy doprecyzować założenia badawcze konkretnie dla niniejszego tekstu. $\mathrm{Na}$ jego potrzeby określiliśmy szczegółowe cele, pytania badawcze oraz hipotezy (tabela 1). 
Tabela 1. Hipotezy, cele i pytania badawcze artykułu

\begin{tabular}{|c|c|c|}
\hline Cele badawcze & Pytania badawcze & Hipotezy badawcze \\
\hline $\begin{array}{l}\text { CB1: Przedstawienie danych } \\
\text { w kontekście zmiennych de- } \\
\text { mograficznych (to jest płci, } \\
\text { wieku i miejsca zamieszka- } \\
\text { nia) }\end{array}$ & $\begin{array}{l}\text { PB1: Które zmienne demo- } \\
\text { graficzne najbardziej wpły- } \\
\text { wają na wybór nośników so- } \\
\text { cial media? }\end{array}$ & $\begin{array}{l}\text { H1: Ze względu na przywią- } \\
\text { zanie młodych pokoleń do } \\
\text { internetu i technologii mo- } \\
\text { bilnych, zmienną demogra- } \\
\text { ficzną najbardziej różnicu- } \\
\text { jącą użytkowanie urządzeń } \\
\text { umożliwiających dostęp do } \\
\text { social media jest wiek użyt- } \\
\text { kowników }\end{array}$ \\
\hline $\begin{array}{l}\text { CB2: Omówienie zakresu ko- } \\
\text { rzystania z urządzeń umożli- } \\
\text { wiających dostęp do mediów } \\
\text { społecznościowych w rozróż- } \\
\text { nieniu na grupę polskich in- } \\
\text { ternautów oraz występujących } \\
\text { pośród nich osób cierpiących } \\
\text { na niski, średni i wysoki wskaź- } \\
\text { nik FOMO }\end{array}$ & $\begin{array}{l}\text { PB2a: Które urządzenia są } \\
\text { najpopularniejsze wśród osób } \\
\text { wysoce sfomowanych, a które } \\
\text { wśród pozostałych grup ba- } \\
\text { danych? } \\
\text { PB2b: Czy dane dotyczące } \\
\text { zmiennych demograficznych } \\
\text { wiążą się ze stopniem sfomo- } \\
\text { wania odbiorców? }\end{array}$ & $\begin{array}{l}\mathrm{H} 2 \text { : W celu korzystania } \mathrm{z} \text { me- } \\
\text { diów społecznościowych oso- } \\
\text { by wysoce sfomowane częściej } \\
\text { sięgają po urządzenia mobil- } \\
\text { ne oraz nośniki mniej popu- } \\
\text { larne, takie jak na przykład } \\
\text { smartwatch lub konsola }\end{array}$ \\
\hline
\end{tabular}

Źródło: opracowanie własne.

3.1. Nośniki umożliwiające dostęp do mediów społecznościowych — wyniki badań

Niniejsza część artykułu odnosi się do CB1, dążąc do odpowiedzi na PB1 i weryfikacji $\mathrm{H} 1$.

Wykres 3 przedstawia odpowiedzi ogólnej grupy badanych (internautów powyżej 15. roku życia) na temat wyborów urządzeń w celu korzystania z mediów społecznościowych.

Najpopularniejsze są smartfony i laptopy lub netbooki ${ }^{40}$. Pozostałe nośniki zajmują dalsze miejsca, notując wyraźnie spadki wobec lidera i wicelidera rankingu. Są to kolejno: komputer stacjonarny, tablet, telewizor i na końcu ex aequo smartwatch i konsola. Prym wiodą więc powszechnie dostępne urządzenia mobilne, ranking zaś zamyka sprzęt cieszący się mniejszym zainteresowaniem, pod względem funkcji niekojarzący się jednoznacznie z użytkowaniem social mediów.

Warto zadać pytanie, czy zmienne demograficzne modyfikują ranking.

${ }^{40}$ We wszystkich dalszych analizach w tekście odpowiedzi „często” i ,zawsze” traktuje się łącznie. 


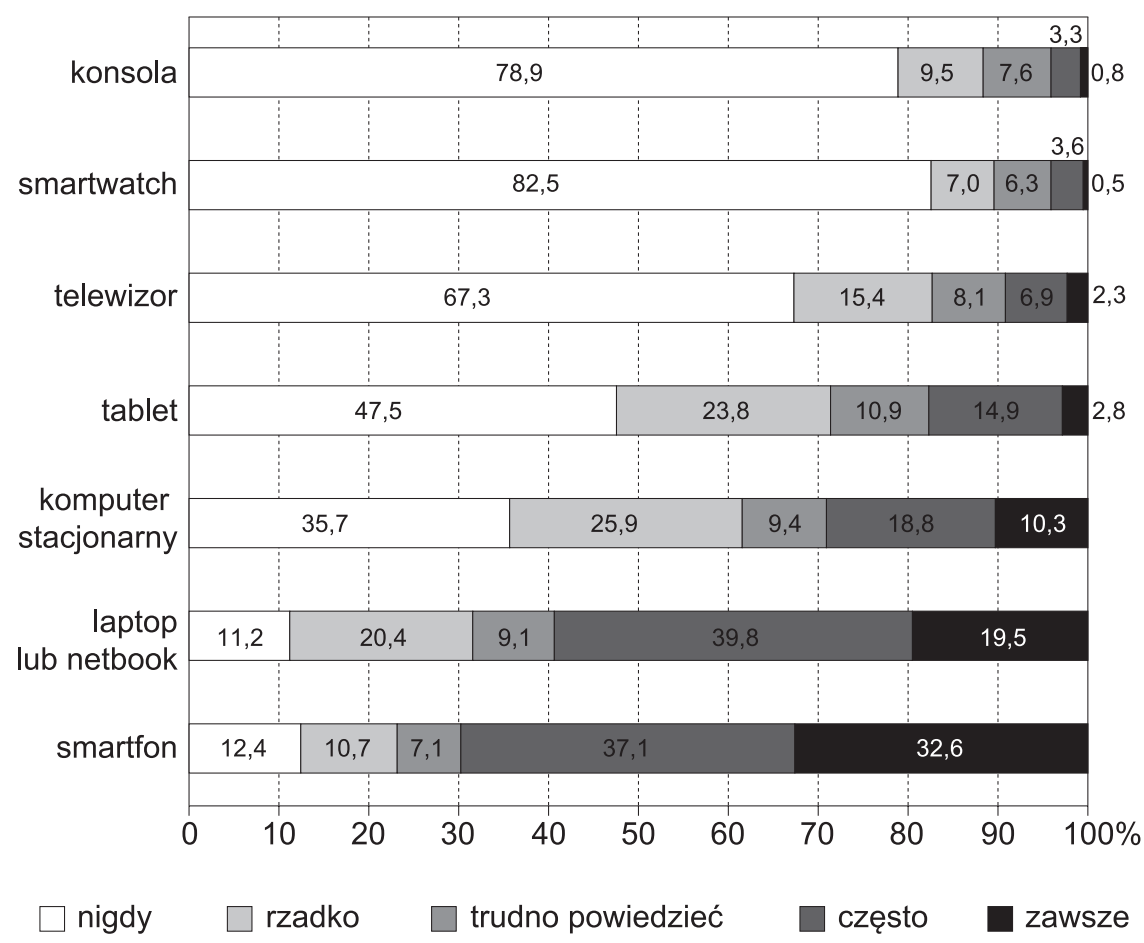

Wykres 3. Płeć a wybór nośników umożliwiających korzystanie z mediów społecznościowych

Źródło: opracowanie własne.

Dane dotyczące płci przedstawia wykres 4 . Widać, że kobiety najczęściej posługują się smartfonem, następnie laptopem, komputerem stacjonarnym, tabletem, telewizorem, konsolą i smartwatchem. Mężczyźni postępują niemal identycznie, zamieniając jedynie kolejność dwóch ostatnich nośników. Należy jednak pamiętać, że o faktycznym wpływie zmiennej na wyniki świadczy nie tylko hierarchia wyboru, lecz także wahania w poziomie odpowiedzi. I tak, w celu korzystania z social media to kobiety zauważalnie chętniej sięgają po smartfony (około 79\% do około 61\% panów). Mężczyźni z kolei częściej wybierają komputery stacjonarne (37\% wobec $21,2 \%$ pań). W wypadku laptopów/netbooków, tabletów, telewizorów, smartwatchy i konsoli różnice są zaś niewielkie i wynoszą od około 1\% (przy tabletach) do 3\% (przy pozostałych nośnikach) na korzyść panów.

Można założyć, że - po pierwsze - płeć umiarkowanie wpływa na wybór nośników, największe zaś różnice dotyczą sprzętu powszechnego dostępu. Po drugie, w odniesieniu do popularnych nośników (takich jak smartfon, laptop/ netbook oraz komputer) to raczej kobiety preferują technologie mobilne. Po trzecie, za pomocą sprzętu mniej powszechnego lub kojarzonego głównie ze swoimi pierwotnymi funkcjami (smartwatch, konsola) z social mediami chętniej łączą się panowie. 


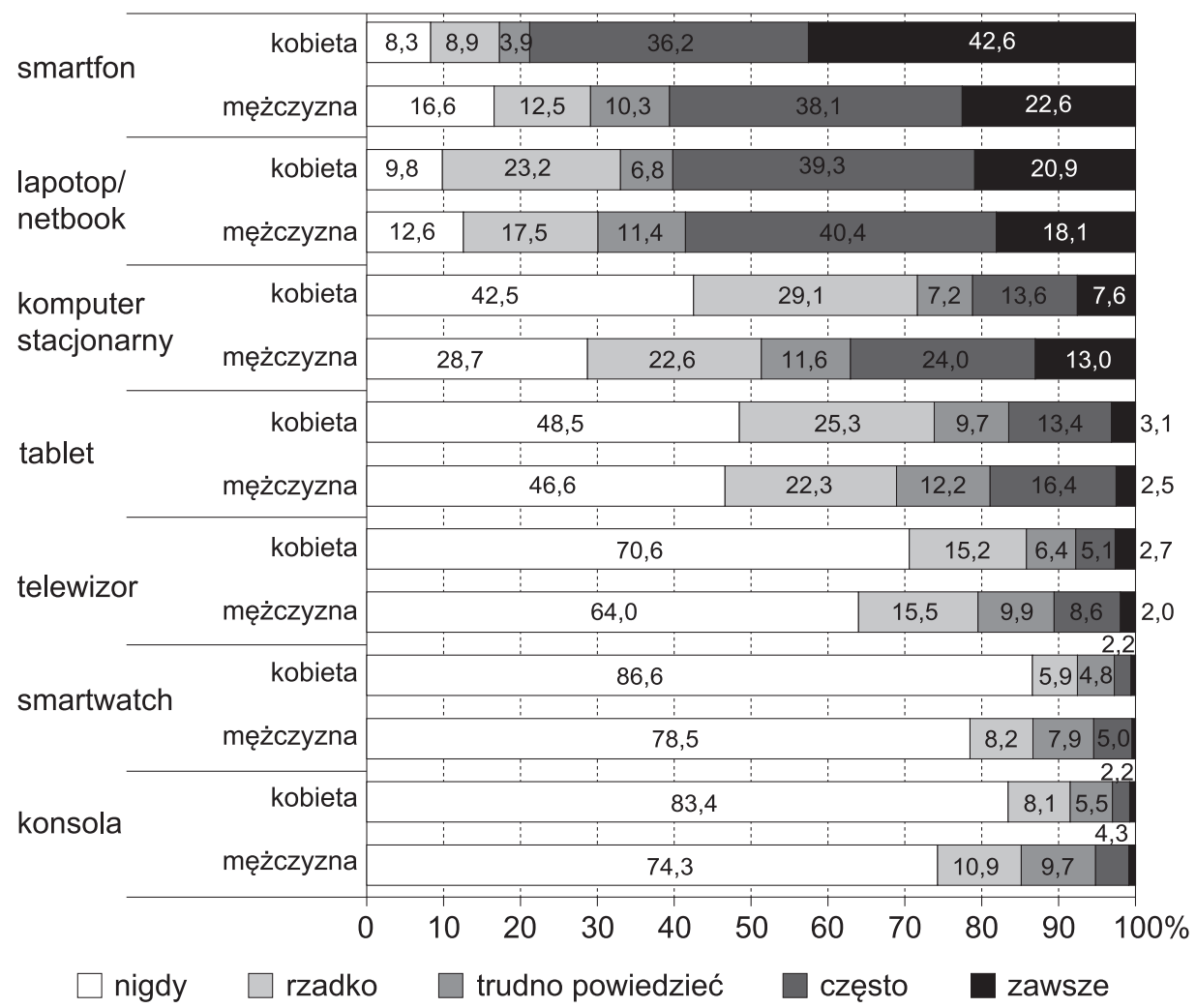

Wykres 4. Płeć a wybór nośników umożliwiających korzystanie z mediów społecznościowych

Źródło: opracowanie własne.

Dane dotyczące drugiej zmiennej — miejsca zamieszkania — obrazuje wykres 5 . Widać tu pewne prawidłowości: różnice występujące między kolejnymi grupami są zazwyczaj niewielkie i wynoszą maksymalnie około $4 \%$. Wyjątki pojawiają się na przykład w wypadku laptopów/netbooków (między odpowiedziami mieszkańców małych i średnich miast a dużych miast), tabletów (między deklaracjami mieszkańców małych i średnich miast, dużych miast i wielkich miast) oraz telewizorów (odnośnie do wskazań mieszkańców małych i średnich miast w porównaniu do dużych miast). Poza tym szczególnie przy powszechnych urządzeniach widać, że częstotliwość łączenia się z mediami społecznościowymi przez nośniki zwiększa się wraz z wielkością miejscowości. Mieszkańcy wsi oraz małych i średnich miejscowości odpowiadają w sposób dość zbliżony, podobnie jak mieszkańcy dużych i wielkich miast.

Zaburzenia wspólnoty odpowiedzi widać najwyraźniej w przypadku tabletów i smartwatchy (tu deklaracje mieszkańców wielkich miast są zbliżone do mieszkańców wsi) oraz konsoli (podobne stanowiska mieszkańców małych i średnich miast oraz wielkich miast). 
Warto dodać, że w celu łączenia się z mediami społecznościowymi mieszkańcy sięgają:

- na wsi po smartfon (około 68\%), następnie laptop/netbook (ponad 55\%), komputer stacjonarny, tablet, telewizor, smartwatch i konsolę;

- w małych i średnich miastach po smartfon (około 69\%), następnie laptop/netbook (ponad 56\%), komputer stacjonarny, tablet, telewizor, konsolę i smartwatch;

- w dużych miastach po smartfon (ponad 72\%), nastepnie laptop/netbook (ponad 55\%), komputer stacjonarny, tablet, telewizor, smartwatch i konsolę;

- w wielkich miastach po smartfon (ponad 73\%), potem laptop/netbook (około 70\%), komputer stacjonarny, tablet, telewizor, konsolę i smartwatch.

Ścieżka doboru urządzeń jest więc zbliżona do odpowiedzi grupy ogólnej (odejścia od schematu pojawiają się przy konsolach i smartwatchach). Warto jednak podkreślić, że w wypadku wielkich miast różnice między korzystaniem ze smartfonów a laptopów/netbooków są najmniejsze. To z kolei każe domniemywać, iż w kontekście użytkowania mediów społecznościowych rezydenci metropolii preferują popularne nośniki przenośne.

Co ciekawe, odnośnie do smartfonów, laptopów/netbooków i komputerów stacjonarnych mieszkańcy wsi i małych oraz średnich miejscowości odpowiadają w sposób zbliżony do grupy ogólnej, z kolei mieszkańcy dużych i wielkich miast uzyskują wyniki powyżej średniej. Wyjątek stanowi tu na przykład tablet (co do którego do średniej równają także rezydenci największych miejscowości) oraz telewizor (przedstawiciele metropolii wypadają poniżej przeciętnej).

Na podstawie przeprowadzonej analizy można ostrożnie wnioskować, że miejsce zamieszkania nieco mocniej niż płeć wpływa na wybór urządzeń przeznaczonych do korzystania z mediów społecznościowych.

Wiek jest ostatnią zmienną demograficzną wybraną do niniejszej analizy (wykres 6).

Przede wszystkim widać, że po smartfony sięgają respondenci z przedziału wiekowego 15-34 lata (ponad 80\% osób) oraz 35-44 lata (ponad 70\%). W starszych grupach wiekowych poziom odpowiedzi „często" i „zawsze” spada, by w grupie wiekowej 55+ osiągnąć wartość około 35\%. Innymi słowy, widać, że użytkowanie smartfonów bezpośrednio wiąże się z wiekiem i jest do niego odwrotnie proporcjonalne (to znaczy spada, im respondenci są starsi).

W przypadku laptopów i netbooków zależności nie są aż tak zauważalne. Poziom odpowiedzi pozytywnych waha się między 53\% a 64\%, przy czym nośniki te służą najczęściej osobom najstarszym (około 64\%) oraz z grupy 25-34 lata (około $62 \%)$. Komputer stacjonarny natomiast najczęściej wybierają respondenci powyżej 45. roku życia (około 40\%), najrzadziej zaś osoby z przedziału 25-34 lata. Tablet preferują badani w przedziale wiekowym 24-54 lata (około 19-20,6\%), w przeciwieństwie do najmłodszych (około 12\%) i najstarszych badanych (około 17\%). 


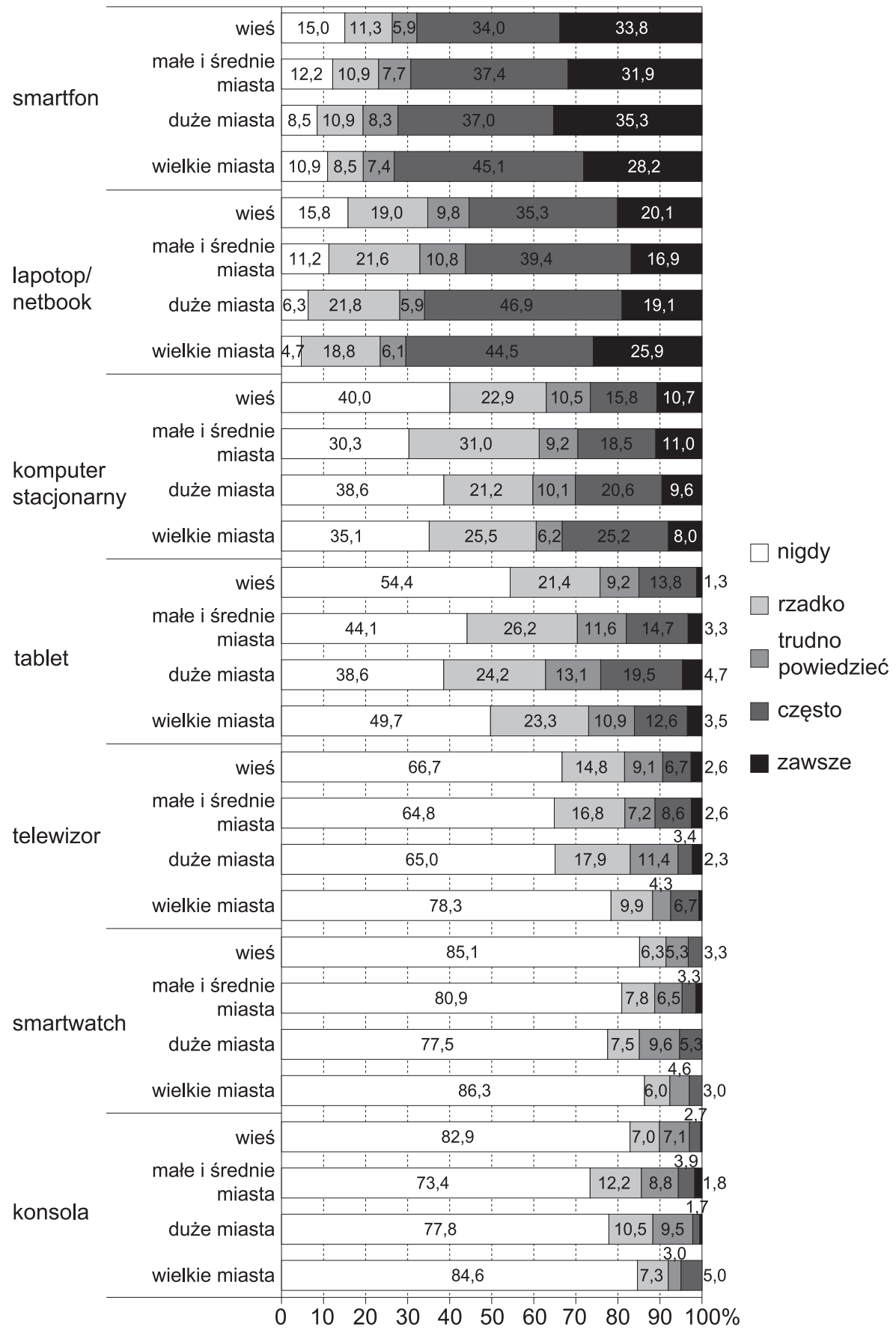

Wykres 5. Miejsce zamieszkania a wybór nośników umożliwiających korzystanie z mediów społecznościowych

Źródło: opracowanie własne.

Forum Socjologiczne 9, 2018

(C) for this edition by CNS 
Telewizor, konsola i smartwatch ponownie cieszą się najmniejszą popularnością wśród badanych, niemniej warto podkreślić tu pewne kwestie. Odbiornik TV jako nośnik social mediów najczęściej służy najmłodszym (około 11\%), a najrzadziej najstarszym. Smartwatch i konsola są użytkowane przez respondentów z przedziału wiekowego 25-44 lata (5-6\% odpowiedzi), niemal w ogóle zaś przez osoby z grupy $55+$ (poniżej 1\%). W obu przypadkach korzystanie z tych nośników zależy od wieku: im ktoś jest starszy, tym rzadziej po nie sięga. Spostrzeżenie to nie dotyczy najmłodszej grupy - można założyć, że z racji jej specyfiki (uczniowie, studenci, zazwyczaj osoby o mniejszej zasobności portfela). Sporadyczne używanie konsoli czy też smartwatcha może wynikać z ograniczonych możliwości zakupowych albo też z innego nawyku odnośnie do łączenia się z social mediami (jak widać, tu prym wiedzie smartfon).

Poszczególne grupy wiekowe sięgają po nośniki w następującej kolejności:

- 15-24 lata - głównie smartfon (86\%), następnie laptop/netbook (około 60\%), komputer stacjonarny (około $28 \%$ ), tablet (12\%), telewizor, konsola i smartwatch;

- 25-34 lata - ponownie smartfon (około 81\%), laptop/netbook (około $62 \%$ ), następnie komputer stacjonarny, tablet (oba powyżej $20 \%$ ), telewizor, konsola i smartwatch;

- 35-44 lata - znowu smartfon (około 71\%), laptop/netbook (około 53\%), następnie komputer stacjonarny (około 29\%), tablet (19\%), telewizor, smartwatch i konsola;

- 45-54 lata - tu następuje istotna zmiana i pierwsze miejsce zajmuje laptop/ netbook (około 59\%), smartfon jest na drugim miejscu (około 53\%), następnie komputer stacjonarny (około 39\%), tablet (około 20\%), telewizor oraz ex aequo smartwatch i konsola;

- 55 i więcej - znowu na pierwszym miejscu jest laptop/netbook (około $64 \%$ ), na drugim - komputer stacjonarny (37\%), na trzecie miejsce spada smartfon (około 35\%), potem tablet (około 17\%), telewizor, smartwatch i konsola.

Zatem wiek wyraźnie różnicuje wyniki w stosunku do danych ogólnych, na przykład o ile zmiany w deklaracjach między mniej powszechnymi sprzętami nie są aż tak znaczne, o tyle nie sposób ich nie zauważyć przy urządzeniach popularnych. Okazuje się, że w poszczególnych podgrupach zmienna wpłynęła na rozkład deklaracji potwierdzających korzystanie z mediów społecznościowych za pomocą konkretnych nośników. Widać to szczególnie w wypadku smartfona (lidera wszystkich pozostałych zestawień): nie jest on najpopularniejszy wśród respondentów powyżej 45. roku życia: jego pozycję zajmuje laptop i netbook, a pośród osób najstarszych ubiega go jeszcze komputer stacjonarny (hipoteza H1 została więc zweryfikowana pozytywnie). 


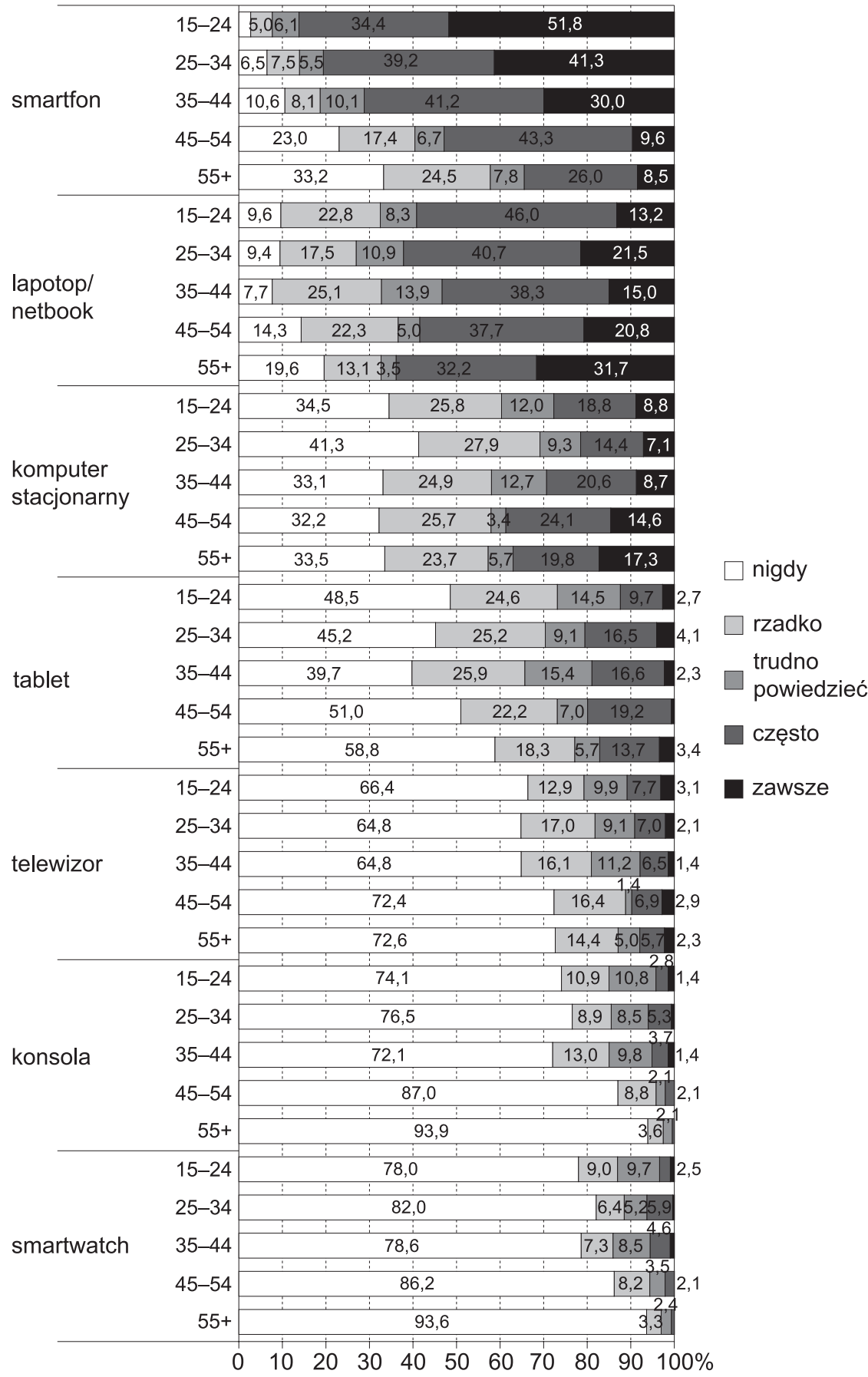

Wykres 6. Wiek a wybór nośników umożliwiających korzystanie z mediów społecznościowych Źródło: opracowanie własne. 
3.2. Fear of missing uut a nośniki umożliwiające dostęp do mediów społecznościowych — wyniki badań

Ta część artykułu odnosi się do CB2, dążąc do odpowiedzi na PB2a i b oraz weryfikacji $\mathrm{H} 2$.

Dane przedstawione na wykresie 7 odnoszą się do osób z grup nisko, średnio oraz wysoce sfomowanej. Dla dodatkowego uwypuklenia specyfiki poszczególnych grup dodano także uśrednione wyniki grupy ogólnej, czyli przeciętnych internautów powyżej 15. roku życia ${ }^{41}$.

Okazuje się, że wyniki respondentów kwalifikujących się do średniego FOMO są bardzo zbliżone do wyników grupy ogólnej: tu różnice między natężeniem korzystania $\mathrm{z}$ danych urządzeń zamykają się w przedziale od około 1\% (przy konsolach, po które chętniej sięgają osoby z grupy ogólnej) do około 2,5\% (przy laptopach, nieco popularniejszych wśród przeciętnych internautów ${ }^{42}$ ). Hierarchia użytkowania nośników przedstawia się więc niemal identycznie. Są to: smartfon, laptop/netbook, komputer stacjonarny, tablet, telewizor oraz — w przypadku grupy ogólnej ex aequo - konsola i smartwatch, a w przypadku średniego FOMO - konsola przed smartwatchem (warto nadmienić, że przez osoby średnio sfomowane częściej wybierany jest tylko smartfon - o 1,4\%).

Interesujących danych dostarcza porównanie wyników grupy ogólnej z grupą o niskim poziomie „sfomowania”. W tym zakresie różnice między nimi są znacznie większe i zdywersyfikowane. Wynoszą one od 0,1\% (osoby o niskim FOMO wybierają laptopy i netbooki), przez 2\% (po komputery stacjonarne też częściej sięgają „nisko sfomowani”), przedział 3,5-4,5\% (tablet, smartwatch czy konsolę preferują osoby z grupy ogólnej), aż po niemal 16\% (tylu badanych z najniższym FOMO rzadziej używa smartfonów).

Okazuje się też, że w grupie niskiego fear of missing out kolejność korzystania z nośników ulega modyfikacji i przedstawia się następująco: laptop/netbook, smartfon, komputer stacjonarny, tablet, telewizor, konsola i smartwatch. Ta istotna zmiana na pozycji lidera najbardziej koresponduje $\mathrm{z}$ wiekiem badanych. Pamiętając o tym, że niskie FOMO rośnie wraz z wiekiem oraz że osoby z grupy 44+ w celu korzystania z mediów społecznościowych częściej sięgają po laptopy i netbooki niż po nowoczesne smartfony, można stwierdzić, że istnieją korelacje między wyborem nośnika, wiekiem a niskim poziomem FOMO. Osoby odczuwające niewielki lęk przed odłączeniem (wśród których najliczniejszą grupę stanowią respondenci powyżej 44. roku życia) preferują raczej tradycyjne nośniki, niemal rezygnując ze „sprytnych urządzeń” i także rzadziej korzystając ze smartfonów.

Do podobnych wniosków prowadzi analiza porównawcza wyników grupy ogólnej z grupą o wysokim poziomie „sfomowania”. Po pierwsze, różnice między grupą ogólną a tą z wysokim FOMO są tu dużo większe i wszystkie wskazują,

\footnotetext{
${ }^{41} \mathrm{Na}$ rysunku nie zaznaczono danych poniżej $2 \%$.

42 Biorąc pod uwagę połączone odpowiedzi „często” i ,zawsze”.
} 
że „fomersi” znacznie intensywniej używają praktycznie każdego sprzętu pozwalającego im na korzystanie z mediów społecznościowych. Mianowicie, o 6\% więcej osób z wysokim fear of missing out sięga częściej po komputer stacjonarny, około $8 \%$ - po konsolę, około $10 \%$ - po smartwatch i laptop, około $12 \%$ - po telewizor oraz smartfon, a niemal $15 \%$ po tablet.

Należy dodać, że hierarchia korzystania z nośników w stosunku do grupy ogólnej niewiele się zmienia: modyfikacja następuje dopiero na ostatnim miejscu (to znaczy smartwatch wysuwa się nieznacznie przed konsolę). Wydaje się jednak, że dużo bardziej znacząca jest skala zmian i wspomniane zwiększenie poziomu odpowiedzi twierdzących, zauważalne przy wszystkich nośnikach (co ciekawe, najsłabiej w tym kontekście wypadł komputer stacjonarny jako właściwie jedyny sprzęt tradycyjnie i od wielu lat kojarzący się ze światem cyfrowym).

Dane ponownie korespondują $\mathrm{z}$ wiekiem respondentów. Skoro wysokie FOMO jest do niego odwrotnie proporcjonalne, a osoby z przedziału 15-24 lata w celu używania mediów społecznościowych najczęściej sięgają po smartfony (nieznacznie rzadziej czynią to badani między 25. a 44. rokiem życia), to również tutaj można potwierdzić korelacje między wyborem nośnika, wiekiem a wysokim poziomem FOMO. Oznacza to, że najmłodsi oraz tak zwani młodzi dorośli odważniej używają urządzeń, takich jak konsola czy smartwatch, przy czym niezaprzeczalnym centrum ich cyfrowego świata pozostaje smartfon (tym samym za prawdziwą można uznać hipotezę szczegółową H2).

Na koniec warto zadać pytanie o to, czy pozostałe zmienne w jakikolwiek sposób korespondują z niskim i wysokim poziomem FOMO.

Jeśli chodzi o płeć, to takie relacje - poza zbliżoną hierarchią korzystania z nośników - są niewielkie. Jak już wskazywano, w Polsce płeć respondentów nie wiąże się znacznie z natężeniem występowania FOMO (szczególnie w kontekście deklaracji o spolaryzowanym charakterze). Tymczasem okazuje się, że płeć umiarkowanie wpływa na wybór nośników, a największe różnice dotyczą sprzętu powszechnego dostępu, takiego jak smartfony oraz komputery stacjonarne (i są to zauważalne różnice, sięgające kilkunastu procent).

W przypadku miejsca zamieszkania wnioskowano, że nieco mocniej niż płeć wpływa ono na wybór urządzeń w celu korzystania z mediów społecznościowych (głównie odnośnie do smartfonów, laptopów i netbooków oraz komputerów stacjonarnych). Również związki między stopniem „sfomowania” a wielkością miejscowości są większe. Przy laptopach/netbookach, komputerach stacjonarnych, tabletach, mieszkańcy wsi zazwyczaj uzyskiwali mniejsze wartości (a więc zbliżone do niskiego FOMO), mieszkańcy zaś dużych i wielkich miast - większe (a więc zbliżone do wysokiego FOMO). Wyraźnym wyjątkiem był tu smartfon, który uzyskał znacznie mniej odpowiedzi twierdzących w grupie osób nisko „sfomowanych”, a w grupie wysoce „sfomowanych" był wybierany zdecydowanie ponad przeciętną, wynikającą z każdej podgrupy zmiennej demograficznej. Można zatem stwierdzić, że w przypadku miejsca zamieszkania istnieje korelacja między FOMO, wielkością miejscowości a wyborem nośnika, przy czym odnosi się ona do wybranych kategorii, składających się na zmienną. 


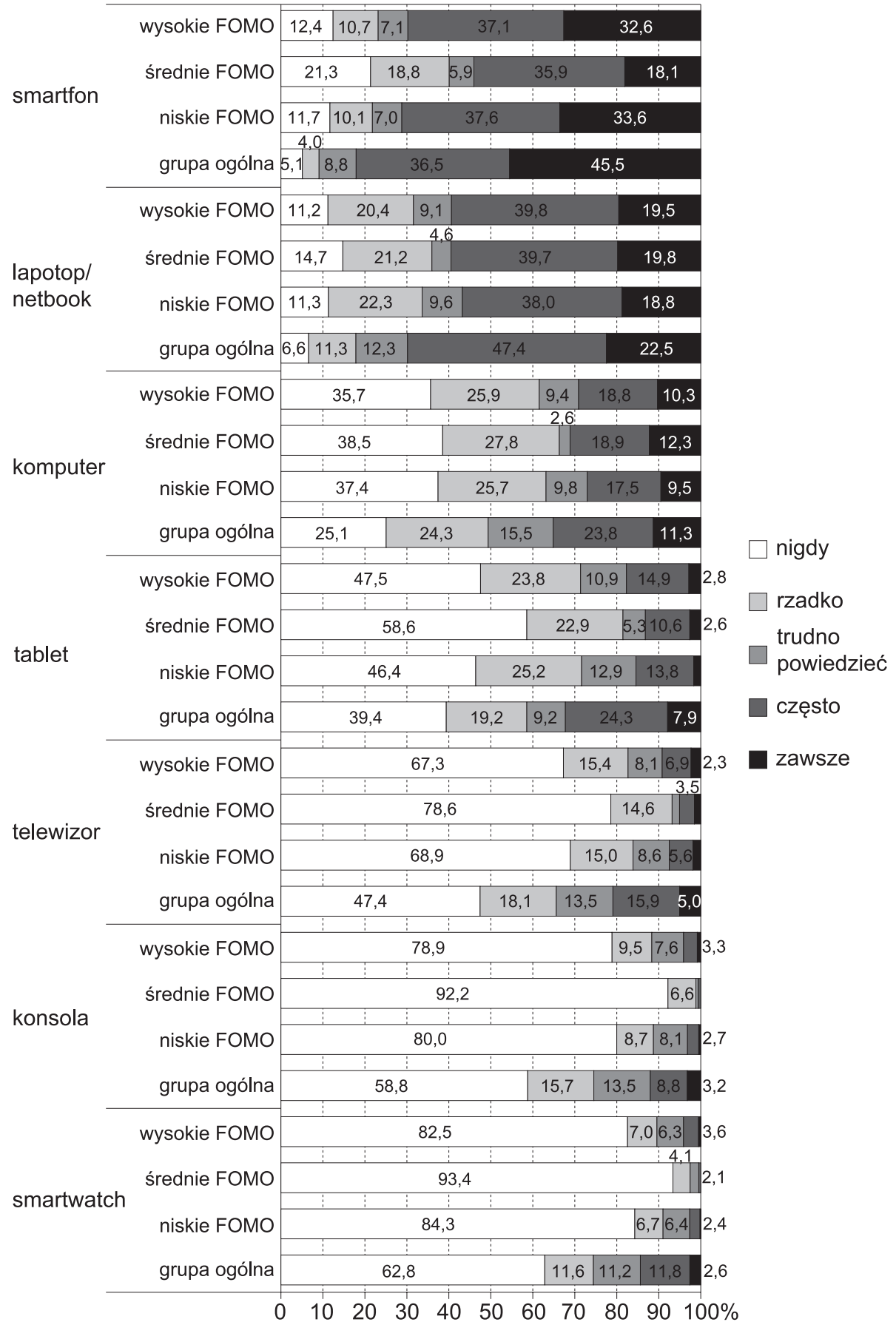

Wykres 7. FOMO wybór nośników umożliwiających korzystanie z mediów społecznościowych Źródło: opracowanie własne. 


\section{Wnioski z badania}

W toku przeprowadzonej analizy obie hipotezy szczegółowe zweryfikowano pozytywnie.

H1: Ze względu na przywiązanie młodych pokoleń do Internetu i technologii mobilnych zmienną demograficzną najbardziej różnicującą użytkowanie urządzeń umożliwiających dostęp do social media jest wiek użytkowników.

Dzięki omówieniu i porównaniu wyników odnośnie do wybranych zmiennych demograficznych okazało się, że wiek najmocniej i najbardziej jednoznacznie wpływa na wybór nośnika w celu połączenia się z mediami społecznościowymi. Różnice widać szczególnie między najmłodszymi i najstarszymi grupami wiekowymi oraz między smartfonem, laptopem/netbookiem a ewentualnie komputerem stacjonarnym. Regułą jest, że młodsi częściej wybierają smartfony, najstarsi zaś - laptopy lub sprzęt niemobilny.

Można więc uznać, że poza wiekiem na wybór urządzeń wpływa, choć w mniejszym zakresie, miejsce zamieszkania (mieszkańcy największych miejscowości dużo chętniej sięgają po smartfon niż respondenci ze wsi) oraz bardzo umiarkowanie płeć (kobiety wyraźnie preferują smartfony). Tym samym, dzięki odpowiedzi na pytanie PB1, zrealizowany został cel badawczy CB1.

H2: W celu korzystania z mediów społecznościowych osoby wysoce sfomowane częściej sięgają po urządzenia mobilne oraz nośniki mniej popularne, takie jak np. smartwatch lub konsola.

Po pierwsze, odpowiedzi twierdzące, udzielane przez osoby o różnym poziomie „sfomowania”, przyjmują rozbieżne zakresy. Co prawda grupa z średnim FOMO zbliżyła się do grupy ogólnej, ale pomiędzy niskim i wysokim FOMO oraz grupą ogólną zarysowały się widoczne odrębności. Okazało się, że spolaryzowani badani odpowiadają poniżej lub powyżej średniej, przy czym warto wskazać, iż w przypadku małego FOMO niektóre wyniki są zbliżone (na przykład przy laptopach i netbookach, komputerach stacjonarnych), co nie ma miejsca przy wysokim FOMO, gdzie wszystkie nośniki wybierane są znacznie częściej.

Po drugie, poziom FOMO wpływa na wybór nośników: „nisko sfomowani” preferowali laptopy i netbooki, a „wysoce sfomowani” — zdecydowanie smartfony. To może wynikać z faktu, że osoby cierpiące na FOMO znacznie częściej korzystają z mediów społecznościowych, dlatego też posługują się wszystkimi nośnikami umożliwiającymi im podłączenie się do internetu.

Po trzecie, zauważono korelacje między stopniem "sfomowania”, wyborem urządzeń a zmiennymi demograficznymi, głównie w zakresie wieku. Otóż osoby starsze (i z dużym prawdopodobieństwem mniej „sfomowane”) rzadziej sięgały po telefon (a także laptop) niż osoby młodsze, które z kolei - podobnie jak „fomersi” - bardzo mocno potwierdzały swoje przywiązanie do tego nośnika. Jeśli zaś chodzi o płeć, korelacje były niewielkie, z kolei odnośnie do miejsca zamieszkania - umiarkowane (odnoszące się do wybranych kategorii, składających 
się na zmienną, gdzie różnice przebiegały na osiach wielkości miasta i doboru nośnika wywodzącego się z grupy urządzeń popularnych).

Tym samym dzięki odpowiedziom na pytanie PB2a (o to, które urządzenia są najpopularniejsze wśród osób wysoce sfomowanych, a które wśród pozostałych grup badanych) oraz PB2b (o to, czy dane dotyczące zmiennych demograficznych wiążą się ze stopniem sfomowania odbiorców) został zrealizowany cel badawczy CB2.

Przy okazji należy podkreślić, że przeprowadzona analiza, której efektem jest pozytywna weryfikacja hipotez szczegółowych, umożliwiła odniesienie się do generalnych hipotez projektu i, summa summarum, potwierdzenie ich prawdziwości w przyjętym zakresie tematycznym. Po pierwsze, faktem jest, że internauci cierpiący na wysokie FOMO wykazują większe niż osoby z tak zwanej grupy ogólnej zainteresowanie cyfrowym aspektem współczesnego życia (HI), to znaczy znaczy częściej i chętniej sięgają po urządzenia mobilne, w tym mniej popularne i trudniej dostępne, takie jak smartwatche czy konsole. Po drugie, wiek to zmienna demograficzna najsilniej różnicująca FOMO w Polsce (HII). Jak wykazano, korelacje między wyborem nośników a stopniem „sfomowania” są najsilniejsze.

$\mathrm{Na}$ koniec warto podkreślić rolę, jaką - patrząc na to przez pryzmat dokonanej analizy — odgrywa obecnie smartfon. Jest to sprzęt, który najbardziej różnicował odpowiedzi zarówno w poziomie FOMO, jak i zmiennych demograficznych. Również na nim w dużej mierze opierały się relacje między fear of missing out, kategoriami demograficznymi a wyborem urządzenia. Można więc założyć, że jego popularność, ze względu na coraz mocniejszą pozycję technologii mobilnych, będzie ciągle rosła. W związku z tym, że osoby o wysokim FOMO najczęściej sięgają właśnie po smartfon w celu łączenia się z mediami społecznościowymi (i że w tej grupie są najmłodsi, co oznacza, iż tendencja ta będzie się utrzymywać), warto zastanowić się, czy smartfon nie jest właśnie urządzeniem, które „fomuje” najsilniej. Z racji jego funkcjonalności, a szczególnie bardzo łatwego dostępu do sieci, można to ostrożnie potwierdzić. Wniosek ten zaś wydaje się istotny w kontekście dobrostanu cyfrowego, w którym jedną z naczelnych reguł jest mądre i zrównoważone korzystanie z nośników ICT.

\section{Podsumowanie}

Fear of missing out to zjawisko wielowątkowe i interdyscyplinarne. Zaprezentowana analiza dotyczy wyłącznie jednego, chociaż ważnego, aspektu tego fenomenu.

Występowanie FOMO - rozumianego zarówno jako system zachowań współczesnego człowieka, konstrukt psychiczny, jak i zjawisko społeczne - w Polsce jest niezaprzeczalnym faktem. Biorąc pod uwagę jego skalę, a także wpływ 
na zdrowie psychiczne czy relacje międzyludzkie, można stwierdzić, że fenomen ten wymaga systematycznych i pogłębionych badań. W naszej opinii nie powinny to być wyłącznie analizy ilościowe, lecz także jakościowe, z wykorzystaniem zróżnicowanych technik i narzędzi badawczych. Pozyskane dane mogłyby wówczas znacznie wzbogacić wiedzę o FOMO, wychodząc poza ramy odpowiedzi deklaratywnych.

\section{Bibliografia}

Allcott H., Gentzkow, Social media and fake news in the 2016 election, „Journal of Economic Perspectives" 2017, $\mathrm{nr} 2$.

Alt D., Students' social media engagement and fear of missing out (FoMO) in a diverse classroom, "Journal of Computing in Higher Education” 2017, nr 2.

Alt D., Students' wellbeing, fear of missing out, and social media engagement for leisure in higher education learning environments, „Current Psychology” 2018, nr 1.

Andreassen C.S., Pallessen S., Griffiths M.D., The relationship between addictive use of social media, narcissism, and self-esteem: Findings from a large national survey, „Addictive Behaviors” 2017, nr 64.

Auverset L., Billings A., Conlin L., Time-shifting vs. appointment viewing: the role of fear of missing out within TV consumption behaviors, „Communication \& Society” 29, 2016, nr 4.

Bajdak A., Nowe media w komunikacji marketingowej przedsiębiorstw, „Handel Wewnętrzny” 2017, nr 2.

Baker Z.G., Krieger H., LeRoy A.S., Fear of Missing Out: Relationships with depression, mindfulness, and physical symptoms, „Translational Issues in Psychological Science” 2, 2016, nr 3.

Barry C.T., Sidoti C.L., Briggs S.M., Reiter S.R., Lindsey R.A., Adolescent social media use and mental health from adolescent and parent perspectives, „Journal of Adolescence” 61, 2017,

Beyens I., Frison E., Eggermont S., „I don't want to miss a thing”: Adolescents' fear of missing out and its relationship to adolescents' social needs, Facebook use, and Facebook related stress, „Computers in Human Behavior" 64, 2016.

Blease C.R., Too many 'friends,' too few 'likes'? Evolutionary psychology and 'Facebook depression', „Review of General Psychology” 19, 2015, nr 1.

Błachnio A., Przepiórka A., Facebook intrusion, fear of missing out, narcissism, and life satisfaction: A cross-sectional study, „Psychiatry Research” 259, 2018.

Buglass S.L. Buglass S.L., Binder J.F., Betts L.R., Underwood J.D.M., Motivators of online vulnerability: The impact of social network site use and FOMO, „Computers in Human Behavior” 66, 2017,

CBOS, (Nad)używanie smartfonów, Komunikat z badań 2018, nr 157.

Collins D., Loss aversion bias or fear of missing out: A behavioural economics analysis of compensation in investor-state dispute settlement, „Journal of International Dispute Settlement” 8, 2016, nr 3.

Dorenda-Zaborowicz M., Marketing w social media, „Nowe Media” 2012, nr 3.

Elhai J.D., Elhai J.D., Levine J.C., Dvorak R.D., Hall B.J., Fear of missing out, need for touch, anxiety and depression are related to problematic smartphone use, „Computers in Human Behavior” 63, 2016.

Fabjanik-Czerniak K., Internetowe media społecznościowe jako narzędzie public relations, [w:] Zarządzanie w sytuacjach kryzysowych niepewności, red. K. Kubiak, Warszawa 2012.

Fox J., Moreland J.J., The dark side of social networking sites: An exploration of the relational and psychological stressors associated with Facebook use and affordances, „Computers in Human Behavior 45, 2015. 
Greenhow C., Lewin C., Social media and education: Reconceptualizing the boundaries of formal and informal learning, „Learning, Media and Technology” 41, 2016, nr 1.

GUS, Sytuacja demograficzna Polski do 2017 r. Urodzenia i dzietność, [b.m.], 2018.

Herman D., The Fear of Missing Out (FOMO), 2010, http://www.danherman.com/The-Fear-of-Missing-Out-(FOMO)-by-Dan-Herman.html.

Hetz P.R., Dawson C.L., Cullen T.A., Social media use and the fear of missing out (FoMO) while studying abroad, „Journal of Research on Technology in Education” 47, 2015, nr 4.

IAB Polska, Raport strategiczny Internet 2017/2018, [b.m.], 2018.

Izba Gospodarki Elektronicznej, Lubię to czy kupuję to, 2016, http://www.ecommercepolska.pl/ files/3814/7074/8959/LubieToCzyKupujeTo_SocialCommerce_Sierpien2016.pdf.

James T.L. James T.L., Lowry P.B., Wallace L., Warkentin M., The effect of belongingness on obsessive-compulsive disorder in the use of online social networks, „Journal of Management Information Systems" 34, 2017, nr 2.

Jaworska A., Jak marki (nie) radza sobie z kryzysem w social media. Przykłady zarządzani w kryzysie, „Nowe Media” 2014, nr 4.

Jupowicz-Ginalska A., Jupowicz-Ginalska A., Jasiewicz J., Kisilowska M., Baran T., Wysocki A., FOMO. Polacy a lęk przed odłaczeniem, Warszawa 2018, http://www.wdib.uw.edu.pl/fomo.

Kiisel T., Is social media shortening our attention span?, 2012, https://www.forbes.com/sites/ tykiisel/2012/01/25/is-social-media-shortening-our-attention-span/.

Knowles K., Meet the man behind FOMO, „The MEMO”, 22.03.2016, https://www.thememo. com/2016/03/22/fomo-patrick-mcginnisbook-the-10-entrepreneur-fomo-meme/.

Kuchciak I., Social media jako element strategii banków opartej na budowaniu relacji z konsumentami, „Zarządzanie i Finanse” 10, 2012, nr 4.

Kuchta M., Ilu użytkowników na świecie korzysta $z$ mediów społecznościowych?, 2017, https:// socialpress.pl/2017/02/ilu-uzytkownikow-na-swiecie-korzysta-z-mediow-spolecznosciowych.

Larkin B.A., Fink J.S., Fantasy sport, FoMO, and traditional fandom: How second-screen use of social media allows fans to accommodate multiple identities, „Journal of Sport Management” 30, 2016, nr 6.

Leoński W., Wykorzystywanie mediów społecznościowych w CSR, „Studia Ekonomiczne. Zeszyty Naukowe Uniwersytetu Ekonomicznego w Katowicach" 2016, nr 300.

Majchrzyk Ł., Jak korzystamy ze smartfonów w 2018 roku?, 2018, https://mobirank.pl/2018/07/02/ jak-korzystamy-ze-smartfonow-w-2018-roku-infografika/.

Majchrzyk Ł., Mobile idigital w 2018 roku w Polsce ina świecie, 2018, https://mobirank.pl/2018/02/02/ mobile-i-digital-w-2018-roku-w-polsce-i-na-swiecie/.

Majchrzyk Ł., Raport „Mobile i digital w 4Q 2018” - prawie 4,2 mld ludzi online!, 2018, https:// mobirank.pl/2018/10/18/raport-mobile-i-digital-w-4q-2018-prawie-42-mld-ludzi-online/.

Marshall T.C., Lefringhausen K., Ferenczi N., The Big Five, self-esteem, and narcissism as predictors of the topics people write about in Facebook status updates, „Personality and Individual Differences” 2015, nr 85.

Mierzejewska K., Technologie informacyjno-komunikacyjne w zarzadzaniu zasobami ludzkimi, „Acta Universitatis Nicolai Copernici. Zarządzanie" 2017, nr 1.

Monacis L., Monacis L., de Palo V., Griffiths M.D., Sinatra M., Social networking addiction, attachment style, and validation of the Italian version of the Bergen Social Media Addiction Scale, „Journal of Behavioral Addictions" 2017, nr 2.

Nowak M., Nie tylko Tiger, czyli 5 największych $w$ Polsce wpadek $w$ mediach społecznościowych, 2018, https://www.spidersweb.pl/2018/03/najwieksze-wpadki-kryzysy-media-spolecznosciowe.html.

Oberst U., Oberst U., Wegmann E., Stodt B., Brand M., Chamarro A., Negative consequences from heavy social networking in adolescents: The mediating role of fear of missing out, "Journal of Adolescence" 55, 2017.

Paliszkiewicz J., Rola mediów społecznościowych w innowacyjnym kształceniu, [w:] Innowacje w zarządzaniu i inżynierii, t. 2, red. R. Knosala, Opole 2016. 
Przybylski A.K., Przybylski A.K., Murayama K., DeHaan C.R., Gladwell V., Motivational, emotional, and behavioral correlates of fear of missing out, „Computers in Human Behavior” 4, 2013.

Radzyński P., Social media w Kościele. Jak je wykorzystywać?, 2015, https://www.deon.pl/religia/ wiara-i-spoleczenstwo/art,1138,social-media-w-kosciele-jak-je-wykorzystywac.html.

Reinecke L. Reinecke L., Aufenanger S., Beutel M.E., Dreier M., Quiring O., Stark B., Wölfling K. \& Müller K.W., Digital stress over the life span: The effects of communication load and internet multitasking on perceived stress and psychological health impairments in a German probability sample, „Media Psychology” 2017, nr 1.

Sadowski R., Raport Newspoint: Pokolenia w Polsce i potrzeba monitorowania ich rosnacej aktywności, 2018, https://blog.newspoint.pl/index.php/2018/03/21/raport-newspoint-pokolenia-w-polscei-potrzeba-monitorowania-ich-rosnacej-aktywnosci/.

Shensa A., Shensa A., Escobar-Viera C.G.,Sidani J.E., Bowman N.D., Marshal M.P., Primack B.A., Problematic social media use and depressive symptoms among U.S. young adults: A nationally-representative study, Social Science \& Medicine" 2017, nr 182.

Sosnowska J., Wyciek danych z Facebooka. 50 milionów kont zagrożonych, 2018, http://wyborcza. pl/7,156282,23981124,wyciek-danych-z-facebooka-50-milionow-kont-zagrozonych.html.

Spohr D., Fake news and ideological polarization: filter bubbles and selective exposure on social media, „Business Information Review” 2017, nr 3.

Stando A., Smartfony mają dla nas różne funkcje. Do tego używamy ich najczęściej, 2018, https://tech.wp.pl/ smartfony-maja-dla-nas-rozne-funkcje-do-tego-uzywamy-ich-najczesciej-6299495768856705a.

Syrkiewicz-Świtała M., Facebook - medium komunikacji marketingowej w ochronie zdrowia, „Zarządzanie Mediami” 2015, nr 3.

Tomczyk Ł., Selmanagic-Lizde E., Fear of Missing Out (FOMO) among youth in Bosnia and Herzegovina - Scale and selected mechanisms, „Children and Youth Services Review” 88, 2018.

Wallace P., Internet addiction disorder and youth, „EMBO Reports” 15, 2014, nr 1, https://www.ncbi. nlm.nih.gov/pmc/articles/PMC4303443.

Walotek-Ściańska K., Ocena poziomu wykorzystania mediów społecznościowych przez teatry publiczne $w$ województwie ślaskim w świetle badań empirycznych, „Studia Ekonomiczne. Zeszyty Naukowe Uniwersytetu Ekonomicznego w Katowicach" 2017, nr 321.

WDIB UW, Media o raporcie „FOMO. Polacy a lęk przed odłaczeniem”, 2018, https://www.wdib. uw.edu.pl/media-o-raporcie-fomo-polacy-a-lek-przed-odlaczeniem.

Winiarska-Brodowska M., Political communication in the EU: Civic potential of new media (case study: Poland), „Central European Journal of Communication” 2018, nr 8.

Wolniewicz C.A., Wolniewicz C.A., Tiamiyu M.F., Weeks J.W., Elhai J.D., Problematic smartphone use and relations with negative affect, fear of missing out, and fear of negative and positive evaluation, „Psychiatry Research” 2018, nr 262.

Woods H.C., Scott H., \#Sleepyteens: Social media use in adolescence is associated with poor sleep quality, anxiety, depression and low self-esteem, „Journal of Adolescence” 51, 2016.

\section{Fear of missing out and the use of devices enabling access to social media (based on the research of Polish Internet users)}

\section{Summary}

The authors analyze preferences of devices enabling access to social media among the Polish internauts aged 15+, in regard to the "fear of missing out" (FOMO) phenomenon. The results of the representative, quantitative survey (CAWI) concerning the selection of devices and tools being used were analyzed according to demographic variables: age, sex, and place of living. The study concluded with a statement that due to huge interest of youth in the internet in mobile technologies, the 
variable most differentiating the selection of devices is the users' age. Respondents from the socalled high FOMO group use mobile devices more often, as well as the devices less popular in general population, like smartwatches or consoles. 